\title{
VIOLENCE, SECTARIANISM, AND THE POLITICS OF RELIGION: ARTICULATIONS OF ANTI-SHI'A DISCOURSES IN INDONESIA
}

\section{Chiara Formichi}

Beginning in April 2000, Indonesian Shi'a communities have been the target of violent attacks, with an escalating increase in reported incidents since 2006. Houses and schools have been burnt down, individuals have had stones thrown at them, and praying sessions have been forcefully disbanded. Across the Muslim world this is hardly news, as sectarian strife has plagued the Middle East and South Asia for decades, if not longer. In Indonesia, however, these attacks are, indeed, a new phenomenon, and one that I am reticent to label as strictly "sectarian" in its origin. ${ }^{1}$

In an attempt to explain why Indonesia has recently experienced a violent turn in approaches to Shi'a Muslims, I situate the surfacing and increase in these attacks in the wider contexts of international politics, changing national political dynamics, legal provisions regulating religious minorities, and the local environment in which the attacks have occurred. Instead of focusing on the micro-dynamics of the attacks, this article concerns itself with the trajectory of the violent turn, bringing national politics

Chiara Formichi is an assistant professor in Southeast Asian Humanities, Department of Asian Studies, Cornell University.

${ }^{1}$ I am grateful to the Koninklijk Instituut voor Taal-, Land- en Volkenkunde (KITLV) in Leiden for hosting me as part of the KNAW project "From Clients to Citizens? Emerging Citizenship in Democratising Indonesia." There, I am most thankful to Gerry van Klinken and Adriaan Bedner for their close reading and valuable feedback on earlier drafts of this article. Parts of it were presented at the "Conference on Minorities in Islam/Muslims as Minorities" (Wake Forest University, October 2012), "Comparative Muslim Societies Program" (guest lecture, Cornell University, October 2012), and at the Sixth Al-Jami'ah Forum, "On Plurality and Minority" (Yogyakarta, December 2013) 
and local dynamics into conversation with legal opinions in both the civil and religious realms. The cases that support this suggested explanation are numerous, but I have elected to present only one detailed case of marginalization and violence, that of the Shi'a community in Nangkernang, a village on the southern coast of Madura island, in the province of East Java.

The decision to pursue a combined analysis focusing on defining moments of transition, and combining local and international perspectives, differentiating between triggers and channels of mobilization in the escalation process, follows Gerry van Klinken's multi-layered study of the violence that swept across Poso and Maluku in 1999-2001. Also, as this article identifies as a turning point the transition period from Suharto's authoritarian New Order (1965-98) to the "democratic" reform era, which spanned 1997-2000, this analysis is heavily influenced by the works of John Sidel and James Siegel. Whereas Sidel's study of religious violence in Java points to the "tensions and anxieties" caused by the recurrent power shifts between secular and religious forces at the national and provincial levels, Siegel's research on the anti-witchcraft campaigns isolates the crisis of identity induced by the collapse of an all-encompassing regime, offering an analysis of the perpetrators. ${ }^{2}$

In this article, the responsibility for shaping the confrontational discourse and violent engagement with the Shi'as is ultimately pinned on the government, through changing contexts and political dynamics. It was the regime that in the 1980s fostered fears of repercussions from the Iranian revolution, thus creating a climate favorable to the condemnation of (alleged) Shi'as; it was government agencies' representatives who in the 1990s joined, thus indirectly legitimizing, "religious" seminars aimed at discrediting Shi'a Islam; and it has been the government in the twenty-first century thus far that has assumed the role of "servant of religious authorities" and encouraged hardline groups concerned with religious deviation to follow their own path to justice. ${ }^{3}$ To balance this state-oriented analysis, which tends to push individual actors, not least the perpetrators of the violence, into the background, this article is also concerned with a more particularist understanding of the violence. By no means do I seek to absolve the individual attackers. Still, as Siegel puts it in the case of the anti-witchcraft campaigns, attacks at the village level are never performed by identifiable individuals, but rather by the massa; and the mob is faceless, "violent and unaccountable." ${ }^{4}$

Approaching the issue of anti-Shi'a discourses and violence as a combination of international, national, and local dynamics, I delineate a more complex picture than that offered by the label of sectarian tensions, and explain the surge in violence as one phase of a long process of "othering." ${ }^{5}$ Each turn was informed by a multiplicity of

\footnotetext{
${ }^{2}$ See Gerry van Klinken, Communal Violence and Democratization in Indonesia (London: Routledge, 2007); John T. Sidel, Riots, Pogroms, Jihad: Religious Violence in Indonesia (Ithaca, NY: Cornell University Press, 2006); and James T. Siegel, "Suharto, Witches," Indonesia 71 (April 2001): 27-78.

${ }^{3}$ This expression is taken from Merle Ricklefs, Islamisation and Its Opponents in Java (Singapore: NUS Press, 2012), p. 288. Ricklefs uses it to comment on the April 2010 Constitutional Court decision to uphold the 1965 Blasphemy Law.

"Siegel, "Suharto, Witches," p. 72.

5 "Othering" is a process of identification of individuals-a visitor or passerby, as well as your neighbor or relative-through characteristics that mark them as intrinsically different from you, and thus potentially dangerous or likely to upset the status quo. The distinction I am making here, by differentiating "a long process of othering" from "mere" sectarianism, points to the fact that anti-Shi'a tensions did not emerge
} 
factors, allowing for the identification of four phases, here identified as: government's concerns about the spread of the spirit of the Iranian revolution in Indonesia (1983-84); reactions to a series of cases of $m u t^{\prime} a h$ temporary marriages (1995); the collapse of the New Order regime (1997-98) with its consequent struggles for power (2000); and the impact of the Majelis Ulama Indonesia's increasing influence in definitions of religious orthodoxy, as illustrated, for example, by the 2005 fatwa on religious deviancy.

\section{Blurred Lines: Indonesia's Shi`a Communities}

With around 2.5 million followers, Shi'a Islam accounts for a small share of Indonesia's vast Muslim population. ${ }^{6}$ Despite being the world's largest Muslimmajority country, Indonesia is built on a state ideology and constitution specifically conceived to reject Islam's political supremacy and, supposedly, to protect religious minorities. ${ }^{7}$ During his Pancasila speech on June 1, 1945, Sukarno invoked: "Let us observe, let us practice religion ... in a civilized way ... with mutual respect for one another. The Prophet Muhammad gave sufficient proofs of tolerance, of respect of other religions; Jesus Christ also showed that tolerance. ${ }^{8}$ Despite such a noble start, however, legal provisions adopted in the following decades have been further narrowing the space for minorities.

In the 1950s and early 1960s, Indonesia was well known in scholarly circles for the richness of its religious traditions and the "syncretism" of Islamic practices that could be observed in Java, Sumatra, and beyond. Yet, in the aftermath of the alleged communist coup of September 30,1965, the incoming Suharto regime granted religious groups the important social role of distinguishing between citizens and "atheist

out of nowhere as due only to "sectarian" differences, but were more deeply rooted in each particular context, as "othering" had been taking place on a variety of levels.

6 "Kang Jalal on Shi'a in Indonesia," Majallah Tempo, September 4, 2012. According to Jalaluddin Rahmat (chairman of Ikatan Jama'ah Ahlul Bait Indonesia, all-Indonesian Assembly of Ahlul Bait Associations, or IJABI), some government statistics report half a million followers, whilst the highest government estimation counts them to five million. According to IJABI, there should be about 2.5 million Shi'a in the archipelago (http: / / www.tempo.co/ read/ news/2012/09/04/055427522, accessed July 16, 2014). According to the Pew Forum on Religion \& Public Life report Mapping the Global Muslim Population (October 2009), Indonesia's Shi' a population is less than 1 percent; this figure is, however, incorrect, as it is based on the official census, which in Indonesia does not distinguish between Sunnis and Shi'as (http:/ / www. pewforum.org/uploadedfiles/Orphan_Migrated_Content/Muslimpopulation.pdf, accessed June 24, 2013).

The proportion of Indonesian Shi'as (1.2 percent) is smaller than the share of Shi'a Muslims in Egypt (approximately 3.75 percent). Compared to Western countries, their numbers are larger than the proportion of Muslims in the United States (0.8 percent) but smaller than those in Europe (4.5 percent), according to the 2010 Pew Forum report The Future of the Global Muslim Population (http:/ / www. pewforum.org/ The-Future-of-the-Global-Muslim-Population.aspx, accessed July 16, 2014). Within the Indonesian context, the comparison with other religious minorities is also useful. Compared to the Muslim majority (generally defined, 87.18 percent), according to the National Census of 2010, there are 6.96 percent Protestants, 2.91 percent Catholics, 1.69 percent Hindus, and 0.72 percent practitioners of Confucianism (http:/ / sp2010.bps.go.id/ index.php/ site/ tabel?tid=321\&wid=0, accessed June 24, 2013).

${ }^{7}$ Besides the quote below from Sukarno's Pancasila speech, the constitutional debate in the 1940s and 1950s put a firm end to the country's religious nationalist wing's hopes for the inclusion of Sharia law in the constitution. See, amongst many, Chiara Formichi, Islam and the Making of the Nation: Kartosuwiryo and Political Islam in 20th Century Indonesia (Leiden: KITLV Press, 2012).

${ }^{8}$ Sukarno, "The Pantja Sila (1945)," in Indonesian Political Thinking, 1945-1965, ed. Herb Feith and Lance Castles (Ithaca, NY, and London: Cornell University Press, 1970), p. 47. 
Communists," gradually reinforcing the concept of orthodoxy. By presidential decree, in 1965, citizens were compelled to declare affiliation to one of the now five officially recognized religions: Catholicism, Protestantism, Islam, Buddhism, and Hinduism. What became known as the "Blasphemy Law" gained much political currency for the persecution of supposed communists in the 1960s, and "deviant" believers in later decades.

Through a series of pulls and pushes described in the next section, Islam found itself in a new role in New Order Indonesia, and during the "Islamic revival" of the 1970 s and 1980s halaqa circles mushroomed at the nation's high schools and universities. ${ }^{9}$ Students gathered in university campuses' mosques at the Technological Institute in Bandung (ITB), Gadjah Mada University in Yogyakarta, as well as in Jakarta and Makassar, where they avidly read Islamist literature in home-made translations from the Arabic and English languages. Like their peers in Egypt and Malaysia, during such group sessions participants discussed the works of prominent Muslim intellectuals, such as Hasan al-Banna, Abu al-'Ala Mawdudi, and Sayyid Qutb, but, interestingly, these representatives of Sunni Islamism were read alongside the works of Murtadha Muthahhari and 'Ali Shari'ati, with no thought given to their "sectarian" allegiances. ${ }^{10}$

It is, indeed, in relation to these developments that Indonesian government officials, and observers more generally, framed the emergence of the first nucleus of Shi'a sympathizers in response to the 1979 Iranian revolution. ${ }^{11}$ This dynamic is further developed in this article, but what needs to be pointed out here is that these "sympathizers," who were mostly inspired by the intellectual sophistication of Shi'a thinkers and its scholars' engagement with metaphysics and logic, and who would, two decades later, bring into existence a mass organization for "lovers of the ahl albait," were by no means the first group of Indonesians committed to a form of Shi'a Islam.

Material evidence, in fact, points to a widespread presence of devotion towards the ahl al-bayt (people of the house, i.e., the Prophet Muhammad, Fatima, Ali, Hasan, and Husayn) in the context of Indonesia, and Muslim Southeast Asia at large, which precedes the Iranian revolution by two, if not three, centuries, and has in the past come to the fore during debates on the Islamization of the region. ${ }^{12}$

\footnotetext{
${ }^{9}$ A halaqa (literally "circle" in Arabic) is a gathering or meeting for the primary purpose of learning about theology, typically Islam. Often there is a primary speaker who presents a specific topic for that halaqa while others sit and listen. Other times multiple speakers will address several topics.

${ }^{10}$ The intellectual context in which Shi'a Islam first emerged in Indonesia is another story. On this see Zulkifli, The Struggle of the Shi'is in Indonesia, ANU E-Press, 2013, available at http: / / press.anu.edu.au?p $=263511$, accessed July 22, 2014. The fact that Sunni and Shi'a authors were being read side-by-side is also mentioned in Martin van Bruinessen, "Genealogies of Islamic Radicalism in Post-Suharto Indonesia," Southeast Asia Research 10 (2002): 126, and it is the focus of Chiara Formichi, "Negotiating Legitimacy through Text: Sources of Textual Authority among Indonesian Shi'a Muslims," under review.

${ }^{11}$ Zulkifli, The Struggle; Hilman Latief, "The Identity of Shi'a Sympathizers in Contemporary Indonesia," Journal of Indonesian Islam 2,1 (2008): 300-35.

${ }^{12}$ See the works by Aboebakar Atjeh from the 1960s and 1970s, including Sit'ah: rasionalisme dalam Islam (Semarang: Ramadhani, 1972); Azyumardi Azra and Nurcholish Madjid's writings from the 1980s and 1990s (e.g., Nurcholish Madjid's introduction to Husain Mohamad Jafri, Awal dan sejarah perkembangan Islam Syi'ah dari saqifah sampai imamah [Jakarta: Pustaka Hidayat, 1989], p. 5.), and the 1960s polemic
} 
The interpretation of these manuscripts, oral traditions, and residual rituals is, however, problematic, and it urges some caution. Rather than using this evidence to argue for a Shi'a past for the population of certain areas of Southeast Asia, ${ }^{13}$ it seems more appropriate to refer to these elements as traces of what Marshall Hodgson defined as "Alid piety," or what Indonesians refer to as "cultural Shi'ism." These terms thus refer to a state of presectarian differentiation of devotional practices that differ rather radically from the programmatic set of belief systems and legal frameworks articulated by the Ithna 'Ashariyyah, Zaidiyyah, or Ismailiyyah branches of Shi'a Islam. ${ }^{14}$

Alongside individuals performing various forms of 'Alid piety and intellectual alumni of the "Islam kampus" phenomenon, the Indonesian community of "lovers of the ahlul bait" also includes followers of Ja'fari figh. Able to take shape only after the fall of the Suharto regime, and mostly present in Indonesia's urban areas, this group is tightly embedded in transnational networks centered in Qom, as it adheres to the ritual modalities promoted by the Islamic Republic and its missionary branch, the Majma Jahani Ahlu Bait (Ahl al-Bayt World Assembly). ${ }^{15}$

Refocusing on the issue of religious minorities and deviation, it then emerges that it was the very existence of a presectarian common ground, and of a community with a blurred internal distinction between Sunnis and Shi'as, that prevented the surfacing of an anti-Shi'a antagonism until the 1980s. This observation bears two further considerations, developed in this article. On the one hand, this situation led to the delay of an official anti-Shi'a discourse until it conflated with political concerns and, more specifically, with the Indonesian government's recognition of Iran's attempt to "export" the revolution. On the other hand, it is worth noting that in broader terms, and despite the recent attacks, Shi'a Muslims still appear to find themselves in a better position than other Muslim minorities (such as the Ahmadis, for example). I suggest that this is because of that original common ground and blurred distinction described above.

around the book Tuangku Rao (Mangaradja Onggang Parlindungan, Pongkinangolngolan Sinambela gelar Tuanku Rao: Terror agama Islam Mazhab Hambali di tanah Batak 1816-1833 (Yogyakarta: LKIS, 2007 [1964]).

${ }^{13}$ Such a suggestion has led some scholars to have to argue for a de-shi'itization of Southeast Asia; citing the work of Brakel (among others), Edwin Wieringa has, for example, advanced the idea of "deShi'itization" in which later developments of Islamization in the Indonesian archipelago "gradually purged ... elements of Perso-Indian origin" to the point that "Shi' itic traces in Indonesian Islam are generally not recognised as such by the common (Sunni) believer." See: Edwin Wieringa, "Does Traditional Islamic Malay Literature Contain Shi' itic Elements? 'Ali and Fatimah in Malay Hikayat Literature," Studia Islamika 3 (1996): 106; and Edwin Wieringa, "Taming a Text: The Incorporation of the Shi' itic Hero Muhammad Hanafiyyah in a Sundanese Version of the Prophetic Tales," in Society and Culture of Southeast Asia: Continuities and Changes, ed. Lokesh Chandra (New Delhi: Aditya Prakashan, 2000), p. 355.

${ }^{14}$ See: Chiara Formichi and R. Michael Feener, eds., Shi' ism in Southeast Asia: 'Alid Piety and Sectarian Constructions (London: Hurst \& Co, 2015); and Marshall Hodgson, "How Did the Early Shi'a become Sectarian?" Journal of the American Oriental Society 75 (1955): 2 . The difference between the two terms being that, in the first case, the devotion directed towards the Prophet's descendants finds its roots in presectarian practices and is often connoted by belonging to this very ancestry (sada and habaib); in the second case, devotees will recognize an old-time Shi' a influence on the Islamization of their region. ${ }^{15}$ Chiara Formichi, "Shaping Shi’a identities in Contemporary Indonesia between Local Tradition and Foreign Orthodoxy," Die Welt des Islams 54 (2014): 212-36. 
$6 \quad$ Chiara Formichi

\section{Seeing the Line: Early New Order and the Shi'as}

\section{Suppressing Political Islam}

Under Sukarno's rule (1945-65), Islam had been forcefully pushed out of politics. Not only had he in the early years marginalized demands for Islam to be part of the state ideology, but his presidency was also marked by the armed repression of the Darul Islam movement and the banning of Masyumi, the major Islamic party. Hence, Suharto's enlisting of Islamic militias to rid the country of "atheist communists" in 1965-66, and his strengthening of individual piety, was seen as a first step towards a more prominent position for Muslim groups in the public sphere under the New Order. Needless to say, Islam was soon to become the new bette noire of the regime.

Suharto's maneuverings to reassert the limits within which Indonesian citizens could uphold Islam was a constant throughout the New Order, and its various manifestations were the result of both domestic and international dynamics. Within the frame of countering communism and providing an avenue for the release of pressures induced by the Islamic revival, the New Order government became supportive of initiatives that "revitalized" and "renewed" Islam as a "cultural" aspect of Indonesians' lives, a depoliticization strategy first developed by Nurcholish Madjid in the 1970s and epitomized by the slogan "Islam yes, Islamic party no!"16

As the distinction between piety and politics became difficult to retain, in the $1970 \mathrm{~s}$ the regime began actively to suppress those religious groups that had transmuted from intellectual gatherings into politicized activism. In 1973, all Islamic parties were forced to merge into the United Development Party (Partai Persatuan Pembangunan, PPP); in 1975, Suharto sponsored the establishment of the Majelis Ulama Indonesia, as yet another way to "co-opt, fragment, and neutralize Islam as an autonomous political force $^{\prime 17}$; and in 1977, the army crushed the militant underground group Komando Jihad in a pre-electoral crackdown. By 1984, these strategies had reached their zenith. As part of its drive for ideological conformity, the government announced the requirement that all organizations declare Pancasila their sole foundational principle. In Jakarta's harbor area of Tanjung Priok, security forces shot at Muslims belonging to a mosque that publicized its anti-Pancasila stand. By the end of the year, the Nahdlatul Ulama withdrew from politics to return to its social mission, accepting Pancasila but also reasserting its own foundations as "based on the faith of Islam." ${ }^{18}$

\footnotetext{
${ }^{16}$ On Madjid and his Islamic renewal (pembaharuan), see Carool Kersten, Cosmopolitans and Heretics: New Muslim Intellectuals and the Study of Islam (London: Hurst \& Co., 2011). On the issue of depoliticization of Islam, see Ricklefs, Islamisation and Its Opponents, pp. 164-67.

${ }^{17}$ Donald Porter, Managing Politics and Islam in Indonesia (London: Routledge, 2002), p. 77.

${ }^{18}$ The asas tunggal policy was announced in 1984, but, because of opposition to it, the law was only passed in 1985. On the Tanjung Priok incident, see "Calm Is Urged in Jakarta after Outbreak of Riots," The New York Times, September 17, 1984, http:/ / www.nytimes.com/1984/09/17/ world/around-the-world-calmis-urged-in-jakarta-after-outbreak-of-riots.html, accessed July 22, 2014; and KontraS Report, Massacre of Tanjung Priok in 1984, http:/ / www.kontras.org/tpriok/data/Massacre\%20of\%20Tanjung\%20Priok\%20 in\% 201984.pdf (Google html cache), accessed August 11, 2014. On Komando Jihad, see Quinton Temby, "Imagining an Islamic State in Indonesia," Indonesia 89 (April 2010): 1-36. On NU, see Robin Bush, Nahdlatul Ulama and the Struggle for Power within Islam and Politics in Indonesia (Singapore: ISEAS, 2009), p. 77.
} 
Suharto was responding to internal as well as external pressures, as the archipelago's Muslims had always been tightly connected to the worldwide $u m m a h^{19}$ and Indonesia could not be seen as insulated from regional and international developments. In 1967, Egypt had lost the Six-Day War, leading to the resurfacing of a further strengthened Muslim Brotherhood. By the 1970s, Islam had become a political force in Malaysia that could not be ignored. In 1979, the Shah was overthrown in Iran, and that same year the Afghan mujahidin started their jihad against the invading Soviet Army. ${ }^{20}$

Amidst these general trends, being identified as Shi'a became a problem in 1980s Indonesia. ${ }^{21}$ Abdul Qodir Balfagih of Bangsri (Jepara, Central Java), who had established a religious school openly teaching Shi'a Islam a few years before the Iranian revolution, pesantren al-Khairat, was targeted by the Ministry of Religious Affairs, as his ideas were labeled "extreme" and inspired by Khomeini's beliefs, teachings, and ideology. ${ }^{22}$ Alerted by the neighboring Sunni community, the religiousaffairs ministry immediately terminated the publication of the school's newsletter. But, although the dissemination of Balfagih's notes and audiocassettes had to be halted, and his followers had to be "guided" to "adapt" to the norms of Sunni Islam, in 1982 the ministerial report concluded that Shi'a Islam could not be banned because of its recognized legitimacy across the Islamic world. Addressing wider political concerns, the report expressly ruled out the possibility of Iran's involvement with the pesantren's activities, and as similarly argued by Tempo magazine, Balfagih's interest in Khomeini lay with the Ayatollah's religious knowledge, not his political views. ${ }^{23}$

In 1983, the Ministry of Religious Affairs issued an internal circular letter reaffirming the principles of the ahlu-l-sunna wa-l-jama'ah, the Sunnis, to ensure that its own staff members would not be influenced by Shi'a Islam. Under the leadership of Syukri Gozali, who had taken over as chairman after HAMKA's (Haji Abdul Malik Karim Amrullah) resignation, the central branch of the Indonesian Council of Ulama (Majelis Ulama Indonesia, MUI) released the first public statement on Shi'a Islam. ${ }^{24}$ In March 1984, a tawisya, or recommendation, warned Indonesian Muslims of the danger of infiltration of Shi'a (and Ahmadi) Islam and advised the population to reject these aliran ("streams"), as they were bound to upset the country's social harmony. The tawisya established the unacceptability of Shi'a Islam on theological grounds, expounding well-rehearsed classical arguments to explain the hiatus between Shi'a and Sunni beliefs. It pointed to the differences in 'ilmu-l-hadith and usul-ul-figh, the

\footnotetext{
${ }^{19}$ Michael Laffan, Islamic Nationhood and Colonial Indonesia: The Umma below the Winds (London: Routledge, 2003).

${ }^{20}$ See: Judith Nagata, The Reflowering of Malaysian Islam: Modern Religious Radicals and Their Roots (Vancouver: University of British Columbia Press, 1984); and Gilles Kepel, Jihad, expansion et déclin de l'islamisme (Paris: Gallimard, 2000).

${ }^{21}$ Azyumardi Azra, for example, who had argued for a Shi'a substratum in the Islamization of the Archipelago, in 1983 defined Khomeini's leadership of the revolution as representative of the influence of "fundamentalist" trends in Islamic societies. Azyumardi Azra, "Typologi gerakan pembaharuan dalam Islam," PanjiMas, August 1, 1983, pp. 44-47. It is also possible that tensions in the Middle East, which had led to a widespread anti-Shi'a literature in Egypt in the 1980s, for example, were reflecting on Indonesia, too

22 "Agama: Khotbah Bilfagih dari desa Bangsri," Tempo, November 20, 1982, pp. 25-26.

${ }^{23}$ Zulkifli, The Struggle, pp. 69 and 511-12.

${ }^{24}$ On MUI and HAMKA's resignations, see Ricklefs, Islamisation and Its Opponents, p. 159.
} 
different concepts and practices of imamah (leadership of the Imams) and khilafah (the "Sunni" caliphate), the Shi'a tenet that the Imams are mas'um (infallible), and the practice of $m u t^{\prime} a h$, temporary marriage ${ }^{25}$ But its political scope was evident.

The MUI was established by Suharto in 1975 with the task of issuing religious opinions, but, instead of being received by Indonesian Muslims as representing religious authority, it was perceived to be a tool of the regime, means for the government to dress security concerns as religious problems. As already pointed out by Barry Hooker, John Olle, and Donald Porter in their respective works, MUI represented yet another attempt to co-opt and bureaucratize Islam. ${ }^{26}$ At this stage it was the state's own concerns that dictated the scope of MUI's agenda, but with the transition to reformasi, the roles were inverted, as illustrated below, with MUI becoming a key actor in defining the boundaries of Islamic orthodoxy and itself influencing legislation. The argument proposed here is that the 1984 fatwa was political in scope regardless of its theological framing.

A leading member of the Majelis, K.H. E.Z. Muttaqien, had claimed that the 1984 tawisya had addressed the concerns of the ummah, as it provided an answer to lay Muslims who were wondering what Shi'a Islam was. Yet, the speeches that accompanied the release of the tawisya show that the MUI's main goal was not to advance the wellbeing of the ummah. Rather, it was to support the regime's politically motivated concern of preventing Iran's revolutionary activism from having an impact on the minds of young Indonesians. Still, today MUI members' own understanding of their duty is to "try to prevent strife and mass violence, which ... could occur as a result of heresy" within the state's own "interest in preventing disturbances." ${ }^{27}$

Commenting at the press conference, two professors from the Islamic state institutes of Jakarta and Yogyakarta, and the minister of religious affairs alike, argued that, although there were no Shi'as in Indonesia, recently there had been a rising interest in Iran's Shi'ism, which the minister described as "a group or a state that ... we should admit is trying to export its revolution abroad, including to Indonesia." The debate was sealed by the chief of police, who explained the real cause of distress: "one

\footnotetext{
${ }^{25}$ Mohammad Atho Mudzhar, Fatwa-Fatwa Majelis Ulama Indonesia: Sebuah Studi Pemikiran Hukum Islam di Indonesia 1975-1988 (Jakarta: INIS, 1993), pp. 114-26. Mudzhar is professor of Islamic law and was for a period head of the Office of Research and Development in the Department of Religion. There are crossreferences to another MUI fatwa, possibly issued in 1983, in Editor, September 16, 1989, pp. 43-44; and Tiras, February 15, 1996, p. 23. The only possible precedent would be the MUI fatwa on "those streams of Islam that reject the sunnah and prophetic hadith" issued in late June 1983; however, here no reference is made to Shi' a Islam specifically. It is interesting to note that in the text of the 1984 tawsiya there was no reference to the 1965 Blasphemy Law, nor to the 1983 fatwa. Also, whereas in the 1997 fatwa against temporary marriage the MUI text explicitly mentions the request as coming from the Ministry of Religious Affairs, the 1984 tawsiya seems to be disconnected from the ongoing debates. See: Himpunan Fatwa MUI sejak 1975 (Jakarta: Sekretariat Majelis Ulama Indonesia, 2011), pp. 114ff.

${ }^{26}$ See: Porter, Managing Politics, p. 78; Barry Hooker, Indonesian Islam: Social Change through Contemporary Fatawa (Honolulu, HI: Hawaii University Press, 2003), p. 60; John Olle, "The Majelis Ulama Indonesia versus 'Heresy': The Resurgence of Authoritarian Islam," in State of Authority: The State in Society in Indonesia, ed. Gerry van Klinken and Joshua Barker (Ithaca, NY: Cornell Southeast Asia Program Publications, 2009), p. 98.

${ }^{27} \mathrm{Ma}$ 'ruf Amin, head of the MUI fatwa commission, commenting on the 1980 fatwa against the Ahmadiyah group in the aftermath of the 2005 attacks on Ahmadis in Bogor. Quoted in Olle, "The Majelis Ulama Indonesia," p. 101.
} 
embassy in Jakarta" was printing and distributing free material "contain[ing] propaganda for the revolution." ${ }^{28}$

Whilst monitoring the presence of Shi'a Islam in Indonesia, the government continued to keep abreast with developments in Iran and its potential consequences for Indonesia. In 1986, LIPI (Lembaga Ilmu Pengetahuan Indonesia, National Institute of Science) released a report that labeled the role of Islam in the revolution as a radical political movement, ${ }^{29}$ and in the same spirit, independent yayasans (foundations) translated anti-Shi'a literature produced in the Middle East and Pakistan, occasionally distributing these books for free. ${ }^{30}$

In the years between 1985 and the end of the Suharto regime Shi'a Islam was the subject of much attention, from the government as well as religious groups concerned with questions of orthodoxy. Anti-Shi'a discourses were increasingly internalized as related to domestic problems, and came to be defined along three parallel and interconnected lines: first, Shi'as were depicted as criminals upsetting the country's social order; second, public religious figures known for their Shi'a sympathies were "accused" of undermining Sunni Islam. Thirdly, religious scholars of various affiliations embraced a dogmatic approach, dedicating their time and efforts to elucidating the doctrinal differences (and social dangers) of Shi'a Islam; the 1980s and early 1990s were dotted with meetings and seminars tackling, either directly or indirectly, the differences between Sunni and Shi'a Islam. This three-fold articulation shows how political, social, and theological concerns were often conflated, with the overall result of conveying a negative image of Shi‘a Islam.

\section{Criminalization}

In 1985, two cases emerged prominently in the news and shed negative light on Shi'a Islam, as the government's security concerns coalesced with those of religious scholars, and court decisions reinforced prejudiced (unfounded) beliefs regarding Shi'a Islam. On January 20 a bomb exploded in Borobudur, the World Heritage Buddhist temple built in the ninth century in Central Java. ${ }^{31}$ Three weeks later, on March 16, another bomb exploded on an express bus headed for Banyuwangi, in East Java. ${ }^{32}$ The cases were investigated conjointly and swiftly solved by the military as "politically motivated |and as| pursued by an extremist group" subscribing to "fundamentalist Islam." A search of the primary suspect's habitation, Habib Husin al-Habsyi's (note the

\footnotetext{
24 "Syiah, kalau-kalau datang," Tempo, March 17, 1984, available at http: / / majalah.tempointeraktif.com/ id/arsip/ 1984/03/17/ AG/mbm.19840317.AG42472.id.html\#, accessed December 9, 2010. In 1986, the Department of Religious Affairs conducted an investigation of Yaumul Quds, the magazine published by the Iranian Embassy in Jakarta, which-because it was written in the Indonesian language-was seen as "an attempt to distribute Iranian revolutionary ideas in the country." These statements and the announcement of the fatwa itself stimulated a lively debate, as laypersons and intellectuals expressed their opinions on the pages of religious and secular magazines, whether they supported the warning or found it superfluous and out of place.

${ }^{29}$ Muhamad Hisyam, Syiah dalam Reoolusi Iran (Jakarta: Lembaga Ilmu Pengetahuan Indonesia, 1986).

${ }^{30}$ See, for example, "Seminar Mencerca Syiah," Tempo, January 23, 1988, p. 85. Common authors were the Pakistani Ihsan Ilahi Zhahir and the Syrian Sa'id Hawwa.

31 "Bom dan Penghuni Kamar Nomor Satu," Majallah Tempo, February 2, 1985, pp. 12-18.

32 “Terdakwa dikeluarkan dari ruang sidang," Surya, November 13, 1990, p. 3.
} 
different spelling, this was not Sayyid Husein al-Habsyi |1921-94|, a prominent Shi'a scholar and founder of YAPI [Yayasan Pesantren Islam, Foundation of Islamic Pesantren], a Shi'a pesantren established in Bangil in the early 1970s), uncovered "a picture of a leader of a foreign nation, a leaflet containing slander against President Soeharto, three books on Shi'a Islam, and 1,478 copies of a book titled Imam Melawan Zionisme [Imam Opposes Zionism], printed in Malaysia." ${ }^{33}$ Further, the investigations revealed that Habib Husin not only had been a student at the pro-Shi'a YAPI school in Bangil-suggesting the involvement of ustadh Husein al-Habsyi ${ }^{34}$-but also that his accomplice in the plot had spent two years and more "in a foreign country that adheres to Shi`a Islam." ${ }^{35}$ The suspect Habib Husin was thus convicted, but his associate escaped, allegedly to Iran. ${ }^{36}$

A decade later, when it emerged that a guru had put together a "deviant sect" that embraced temporary marriage (nikah $m u t^{\prime} a h$ ) to take advantage of underage girls, Shi'a Islam came once again under attack. The news reports did not identify the sect as Shi'a, but guru Ali Hasan was reported to have admitted that he had "taken his teachings from madhhab Jaafari." ${ }^{3 \bar{j}}$ As the practice of nikah mut'ah appeared to be present well beyond the boundaries of Sragen (the small Central Java town where the scandal first surfaced), meetings rapidly ensued among the Ministry of Religious Affairs, various provincial branches of the MUI, and religious organizations to discuss the permissibility of temporary marriage for Muslims in Indonesia. Several religious groups had reached independent resolutions affecting their own membership, but the ultimate goal remained the recognition of this practice as haram for Indonesians at the national level, with the assumption that all Muslims in the country should be Sunnis. This kept open the option of further strengthening the 1984 MUI advice against Shi'a Islam in general. At this time, there was unanimous agreement that nikah mut'ah should not be allowed. ${ }^{38}$

\section{Stigmatization}

On a parallel track to the political, judicial, and religious dynamics described above, throughout the 1990s Nahdlatul Ulama leaders were, at different junctures, "accused" of being Shi'as. In 1993, a representative of Surabaya's al-Bayyinaat (a pesantren specifically committed to the eradication of Shi'a Islam) held Abdurrahman Wahid accountable for "spreading Shi'a thought" amongst NU members, since a few years earlier he had stated that "to be honest, NU itself is a reincarnation of Shi‘a culture." 39 In 1996, these accusations towards Wahid were reiterated once again, and Sayyid Aqil

\footnotetext{
33 "Kasus peledakan bus pemudi segera ke pengadilan," Surabaya Post, A pril 23, 1985, pp. 1, 12.

${ }^{34}$ For a full exploration of ustadh Sayyid Husein al-Habsyi, see Zulkiflili, The Struggle, pp. 69-76.

35 "Usaha menyebarkan faham Syiah pasti dapat tentangan," Jawa Pos, May 21, 1985, pp. 1, 12. However,

"Bom dan Penghuni Kamar Nomor Satu," Majallah Tempo, makes no mention of the Shi'a connection.

36 "Isu Syiah dan Ilusi Ukhuwah," AULA, December 2012, p. 55.

"3 "Mut'ah yang dilakukan Sesama Pengikut," Suara Merdeka, May 17, 1995, p. viii.

SN See: "Kawin Kontrak hukumnya haram," Surya, August 15, 1995, p. 16; and "Aliran Sesat hari ini dibahas oleh Komisi E DPRD Jateng," Suara Merdeka, May 30, 1995, p. viii.

39 "Semangat Qom Imam muda," Editor, September 16, 1989, p. 44, and reprinted in "Syiah disekitar kita," Tiras, February 15, 1996, p. 19. The accusation appears in an interview transcribed in "Membunuh Kecoak dengan Bombardir," AULA, September 1993, pp. 16-20.
} 
Siradj, at the time deputy secretary of the NU Supreme Council, was asked by a group of colleagues to resign from the organization's executive board due to suspicions of him being an "undercover agent" of the Shi'as. Such perception emerged from Siradj's criticism of NU's practice of ahlussunah wal jaamah and his suggestion that Hasyim Asy'ari, the founder of the NU in 1926, was a Shi'a. ${ }^{40}$ This debate internal to Nahdlatul Ulama rapidly brought renewed attention to the presence of Shi'a Islam in the archipelago, its connections to Iran, and its infiltration in Indonesia's educational and political structures. ${ }^{41}$

\section{Dialogue?}

Between criminalization and more general stigmatization, in the late 1980s and 1990s the religious community organized meetings and seminars with the supposed goal of debating Sunni-Shi'a differences. I say "supposed" because, in fact, the vast majority of these events were a platform for "orthodoxy concerned groups" to discredit Shi'a Islam as heresy or, more rarely, occasions for Shi'a sympathizers to counter that trend. In October 1991, the religious school pesantren Darunnajah invited three speakers, hailing from different backgrounds, to lead a seminar on the relations between Sunni and Shi'a, "hoping the discussion could reveal positive aspects bridging between these two madhhab [schools of thought]." The seminar, attended by over six hundred participants and focusing on comparative theological thought, took a sour turn. Din Syamsuddin, chairman of Muhammadiyah, and Muhammad Rasjidi, former minister of religious affairs (1945-46) and Jakarta director of the World Islamic League, a figure known for his views of Shi'ism as deviant, ${ }^{42}$ were eventually "overtaken by emotions," and used inappropriate language and unsophisticated arguments to respond to Jalaluddin Rahmat's paper (or so the Panji Masyarakat reporter thought) to the extent that the debate had to be interrupted. ${ }^{43}$

\footnotetext{
40 "Hasyim Asy'ari hingga Syiah," GATRA, February 17, 1996. The arbitrariness and political character of these accusations is further substantiated by the fact that even a Salafist group can be "accused ... of being Shi'ite." See Ricklefs on the Forum Pemuda Islam Surakarta (FPIS), Ricklefs, Islamisation and Its Opponents, p. 422.

41 "Dari tuduhan Syiah sampai ajakan sumpah mimbar," Tiras, February 15, 1996, p. 20. This is part of a "Special Report" of twenty pages entitled "The Shi'as among us," Tiras, February 15, 1996, pp. 18-30, 47-51.

42 Azra, Islam Reformis, p. 21.

43 "Dialog Syi'ah-Sunni terpaksa dihentikan," PanjiMas, October 21-31, 1991, p. 16. Rasjidi stated that Sunni and Shi'a should overcome their "cultural grudge" and "seek points of similarities [for] the fundamental need of Muslims today is to overcome the problems of their community," quoted in Islam in Indonesia: A Survey of Developments from 1988 to March 1993, ed. Darul Aqsha, Dick van der Meij, and Johan Hendrik Meuleman (Jakarta: INIS, 1995), p. 332. Considering Rasjidi's background and the overall tone of the meeting, one could be inclined to read his comments as a suggestion that Shi" as should "get on with it" and assimilate. On Rasjidi, see Azyumardi Azra, "Guarding the Faith of the Ummah: The ReligioIntellectual Journey of Mohammad Rasjidi," Studia Islamika 1,2 (1994): 87-119. PanjiMas suggests that the bitterness of the clash was "exceptional." Rather, I would suggest that the exceptionality of this event was due to the fact that pro- and anti-Shi' a speakers engaged in, or at least agreed to participate in, an actual debate. In fact, most of the meetings aimed at discussing Shi'a Islam in the 1980s and 90s, in reality, featured only one side of the debate. It is also worth noting that, as of this writing, Din Syamsuddin is still chairman of Muhammadiyah and remains one of the few prominent religious figures arguing that there is not enough evidence to declare Shi'a Islam deviant.
} 
The 1991 Darunnajah event was not unique, although it may have been the liveliest of similar events. At least two events preceded it. In December 1987, a group of progressive thinkers gathered on the grounds of Jakarta's State Islamic Institute to move beyond the 1984 MUI recommendation and foster mutual understanding. On this occasion, Abdurrahman Wahid suggested that "culturally, both NU and Perti [Persatuan Tarbiyah Indonesia, Islamic Education Union] are also Shi'a," and Nurcholish Madjid expressed the belief that "sectarianism and fanaticism only give origin to polytheism." ${ }^{44} \mathrm{~A}$ month later, the association of Middle Eastern Alumni responded by dedicating a one-day seminar to a discussion on "Islamic Doctrine." In fact, it was a one-sided presentation on the misbeliefs and dangers of Shi'a Islam. Here Ibrahim Hosen, representing MUI, stated that Shi'as "are the same as Communists. They call themselves Muslims, but they are the greatest danger for Islam, ${ }^{45}$ to which Mohammad Rasjidi added, "Shi'as are a danger for us Indonesians!"

It was in such a climate that gatherings followed one another. In April 1993, a group of Sunni organizations based in Bangil (including branches of the NU, Muhammadiyah, and Persis, and the pesantren al-Bayyinaat) held a meeting on Sunni Islam in response to a Ahlul Bait gathering hosted at YAPI ${ }^{47}$ In 1992, the Forum Umat Islam in Pekalongan (in Central Java) issued a resolution declaring Shi'a Islam deviant, requesting that the mayor as well the district's representative council endorse the resolution. ${ }^{48}$ A year later, in East Java, local ulamas from NU, Muhammadiyah, and Persis met with the provincial branch of the MUI to discuss Shi'a Islam as heresy and to elaborate a strategy to prevent its dissemination in the region. ${ }^{49}$

The three trends identified above-criminalization, stigmatization, and the refinement of a dogmatic discourse against Shi'a Islam-are generally understood as having first emerged under the aegis of the government's broad tendency to suppress political Islam. But, just as important, those trends also manifested through local incidents and rather specific initiatives. Legal provisions and political discourses targeting Shi'a practices were issued in response to specific "threats" to the social order, whether real (such as the Iranian revolution and the spread of temporary marriage) or alleged (e.g., the 1985 bombings). But in the 1990s, as Suharto pursued a rapprochement with religious hierarchies and voters, these multiple layers were conflated and the religious groups that had so far acted at the local level, within towns,

\footnotetext{
44 "Titik Timbang Sunah Syiah di Ciputat," Maiallah Tempo, December 19, 1987, p. 102.

${ }^{45}$ Aqsha et al., Islam in Indonesia, p. 139. As evidenced by Ricklefs, in 1988 the army had started to identify a new threat in "new-style Communism"; in the years to follow, "the government found opportunities to ring the anti-Communist bell again," as Islamic leaders were also prone to see a risk in "latent Communism." Ricklefs, Islamisation and Its Opponents, pp. 245-49.

46 "Seminar Mencerca Syiah," Majallah Tempo, January 23, 1988, p. 85.

47 "Perang Arab di Bangil," AULA, September 1993, p. 12.

${ }^{48}$ Rahman Zainuddin and Hamdan Basyar, eds., Syi'ah dan Politik di Indonesia: Sebuah Penelitian (Bandung: Mizan, 2000), p. 114. It is worth noting that an organization named "Forum Umat Islam" constituted itself to support and enforce the MUI fatwa that declared the Ahmadiyah deviant, and requested its disbandment. This FUI works as an umbrella for members of MUI, KISDI, DDII, HTI, NU, ICMI, FPI, MMI, PKS, and several other parties or religious organizations. See report by International Crisis Group, "Indonesia: Implications of the Ahmadiyah Decree," Jakarta-Brussels, 2008, p. 3.

${ }^{49}$ See: "Debat Seru tentang Syiah di Alfalah," Jawa Pos, August 3, 1993, p. 2; "Soal Syi'ah, Ulama Jatim bentuk Tim Khusus," Karya Darma, August 4, 1993, p. 2; "Sikap MUI terhadap Syi'ah," AULA, October 1993, p. 54; and "Perang Arab di Bangil," AULA, September 1993, p. 11.
} 
and occasionally provinces, made increasingly strong demands. These groups worked through the attorney general's office and the Ministry of Religious Affairs to persuade the government to match their concerns and thus recognize Shi'a Islam as deviant or heretical by enacting national laws to that effect. Those requests, we have seen, were to no avail, but the year 1997 marked a sea change, as illustrated in the remainder of this article

\section{Drawing the Line: The Late New Order and Transition to Democracy}

Looking at the broader picture, the early to mid-1990s saw the emergence of a modernist Muslim middle class and its gradual incorporation in the regime's hierarchies. This process peaked in 1990 with Suharto's inauguration of ICMI (Ikatan Cendekiawan Muslim Se-Indonesia, Association of Indonesian Muslim Intellectuals), under the leadership of president-to-be Habibie, which provided a channel for the middle classes and bureaucrats to display their piety without alienating government connections. During this phase of the New Order, the performance of open, visible modes of modernist Islam became a way to achieve upward mobility for Muslim civil servants (and their business partners). ICMI's consolidation thus worked in favor of the regime as it "provoked deep tensions in the ranks of the military, confused and frustrated the country's fledgling (and proudly multiconfessional) prodemocracy movement, and unleashed fierce debates in the Muslim community itself," thus weakening all potential opponents. ${ }^{50}$ Whilst some saw ICMI as a further step in the regime's opening to religion, others described the new organization as "sectarian" and aimed at "reconfessionalizing" Indonesian politics and society. ${ }^{51}$

To Sidel, the "ambiguities and tensions" in the relationship between the ascending ICMI network and Suharto's old-time patronage networks impacted both macro-level power balances and micro-level socio-economic structures, eventually finding release through anti-Chinese and anti-Christian violence. What had started as responses to "perceived insults" to Islam, its representatives, or its institutions in the form of "small-scale attacks on Christian churches [by 1995-97 had shifted] to larger and more sustained incidents of religious rioting" in a context of strengthening Muslim piety. ${ }^{52}$

Did this new context exacerbate relations between Sunni and Shi'a as it had between Muslims and non-Muslims? As anticipated by the reactions to the nikah mut'a scandals and further marked by the political ramifications of the accusations against Aqil Siradj, in the second half of the 1990s the anti-Shi'a debate was mounting, yet remained limited to certain circles. In fact, in the early to mid-1990s-the very years between the increasingly confrontational environment described above and the surfacing of "orthodoxizing" trends within the Islamic ummah-the pro-Shi'a community in Indonesia had shown confidence regarding its place in the country's Muslim society. In 1993, Jalaluddin Rakhmat (further discussed below) and Haidar Bagir opened the first Muthahhari school in Bandung that taught aqida and figh

\footnotetext{
${ }^{50}$ Robert W. Hefner, Civil Islam: Muslims and Democratization in Indonesia (Princeton, NJ: Princeton University Press, 2000), p. 128. Specifically, on the emergence of ICMI, see Robert W. Hefner, "Islam, State, and Civil Society: ICMI and the Struggle for the Indonesian Middle Class," Indonesia 56 (1993): 1-35.

${ }^{51}$ Abdurrahman Wahid, quoted in Hefner, Civil Islam, p. 128.

52 Sidel, Riots, Pogroms, Jihad, p. 74.
} 
according to the "five madhahib." ${ }^{53}$ Mizan-the publishing house identified with Shi'a literature-held year-long celebrations for its tenth anniversary, ${ }^{54}$ and Abdurrahman Wahid, chairman of NU, hosted 'Ashura' commemorations in his kampung mosque in Ciganjur, Jakarta. ${ }^{55}$

The tendency toward orthodoxy in the late-Suharto era had little impact on the Shi'a community, arguably giving (at least to its intellectual community) more space for action. The boosting of Shi'a confidence in the early 1990s did not take place despite the strengthening of Sunni modernist Islam in Indonesia, but, rather, because of it, as the initiatives mentioned above could all be read as manifestations of the country's Islamic intellectual and cultural vitality. Pro-Shi'a intellectuals—stigmatized as they were for their statements and actions in that direction-were also plugged into the broader network of Muslim intellectuals: Mizan Press had its roots in the "Islam kampus" movement described above, and now had close ties with ICMI; Haidar Bagir himself was an ICMI activist and the operations' director of its newspaper, Republika; and Quraish Shihab was a member of the Majelis Ulama Indonesia as well as ICMI. ${ }^{56}$

The turning point in Sunni-Shi'a relations in Indonesia can be identified as occurring in late 1997. In this second phase, we see an equal partition of anti-Shi'a discourses, which followed-up from the earlier New Order period: in September 1997, a rather large anti-Shi'a seminar takes place in Jakarta, with the support of all major religious organizations and the participation of representatives of several government bodies; in October 1997, the fragmented legal opinions on temporary marriage are unified in a MUI fatwa; and in March 1998, when Quraish Shihab is nominated as minister of religious affairs, groups "concerned with orthodoxy" launch a campaign to discredit Shihab as a Shi'a sympathizer.

\section{September 1997}

After Golkar (Golongan Karya, Party of the Functional Groups) managed to come out ahead in the May 1997 legislative elections by fracturing the opposition, riots broke out across Java (most notably in Pekalongan) and on the islands of Kalimantan and Sulawesi. By August and September, the Asian financial crisis had caused the rapid fall of the Indonesian rupiah, one of the many consequences of which was the reawakening of Muslim reformist voices. Far from being a unified front, its "secular" and "religious" wings were soon to form an alliance. Amidst this economic, political, and social instability, it was the combination of the weakening of Suharto's image as the strong man of the New Order and the surfacing of a religious political discourse that enabled anti-Shi'a voices, framed as concerns for social disharmony, to become stronger. ${ }^{57}$

\footnotetext{
${ }^{53}$ See: http: / / www.smuth.net/ news.php\#fragment-4, accessed March 25, 2012, and "Dari Qom, ke Bangil dan Pekalongan," Tiras, February 15, 1996, p. 28.

${ }^{54}$ Aqsha et al., Islam in Indonesia, pp. 372-73.

55 "Beda dalam cara, sama dengan tujuan," AULA, October 1993, pp. 40-49.

56 "Ahli Tafsir yang Rendah Hati," Mimbar Ulama 235/ XX, March 1998, p. 11.

${ }^{57}$ Merle Ricklefs points to the same dynamics in the 1996-98 period to explain the explosion of antiChinese and anti-Christian violence; in that context, he focuses on the increasing presence of Islamist groups and the fact that these groups, as well as the regime itself, insisted on the need to suppress the
} 
The maneuvering of Sunni sectarian religious groups reached maturity in September 1997, with a national seminar on Shi'a Islam held at the Istiqlal Mosque in Jakarta. The event, gathering about a thousand participants, had been organized by the Islamic Research and Study Institute (Lembaga Penelitian dan Pengkajian Islam, LPPI), which had been established in 1988 in Jakarta with a commitment to the uprooting of heresy. As noted by Olle, from its inception the LPPI has been leading seminars, publishing books, and-since the fall of Suharto but more markedly since 2005pursuing attacks on "heretic groups" together with other radical groups, such as the Front Pembela Islam (Front of the Defenders of Islam, FPI) ${ }^{58}$ The 1997 seminar, held during the argumentative phase of LPPI's campaign against heresy, obtained the backing of the national organizations NU, Persis, Dewan Dakwa Islamiyyah Indonesia, al-Irsyad, IKMI, and Muhammadiyah, even though it appears that the last of these did not participate at the meeting. ${ }^{59}$ The gathering was supported also by the regional alKhairaat of Central Sulawesi (the largest Hadhrami organization there) and the yayasan al-Bayyinaat of East Java, which, similarly to LPPI, was specifically dedicated to the eradication of Shi'a Islam. Al-Bayyinaat, possibly sponsored from Saudi Arabia, was established in 1986 by Zein al-Kaf, the same personality behind the 2014 "Anti-Shi'a Alliance. ${ }^{\prime 60}$ What is more, as ceremonies were opened by MUI chairman K. H. Hasan Basri, $^{61}$ and participants included representatives of the intelligence service Bakin (State Intelligence Coordination Body), the attorney general, and the ministries of Home Affairs and Religious Affairs, ${ }^{62}$ the event and its accusatory approach offered the impression of having governmental approval.

As had happened in 1984 with the MUI tawisya, the 1997 Istiqlal Mosque seminar was an important juncture in anti-Shi'a discourse, its shock wave washing across civil society and government circles. It is worth noting the appallingly low scholarly level of the interventions, later collected and published through an MUI sponsorship ${ }^{63}$ which were aimed at supporting the LPPI's and backing organizations' request to shut down all Shi'a pesantren and foundations in Indonesia, and ban Shi'a Islam in the country. As confirmed by one of the concluding remarks, the seminar's broader aim was to reaffirm and reinforce well-established misconceptions about Shi'ism, such as the stereotype that "all throughout history Shi'as have been proven to be criminals, traitors, and terrorists." ${ }^{64}$

threats to stability that were surfacing in several quarters. Ricklefs, Islamisation and Its Opponents, pp. 250-51.

${ }^{58}$ Olle, "The Majelis Ulama Indonesia," pp. 97, 108-11.

59 "Seminar yang bukan ilusi," PanjiMas, October 6, 1997, p. 85.

60"World's First Anti-Shia Alliance Convention Results in Calls for Violence and Sectarian Purging," http: / / www.commdiginews.com / world-news/ worlds-first-anti-shia-alliance-convention-results-in-callsfor-violence-and-sectarian-purging-16020/, accessed July 22, 2014.

${ }^{61}$ See: "Para ulama sepekat sulit pertemukan faham Syi'ah-Sunni," Republika, September 22, 1997, p. 2; and

"Seminar yang bukan ilusi," p. 85.

62 "Seminar yang bukan ilusi," p. 85.

${ }^{63}$ Umar Abduh and Abu Hudzaifah, eds., Mengapa kita menolak Syi'ah (Jakarta: Lembaga Penelitian dan pengkajian Islam, 1998).

${ }^{64}$ See: ibid., p. 160; and "Pemerintah agar segera cabut tujuh yayasan Syi'ah," Pelita, September 23, 1997, p. 8 . 
The "unscholarly" character of the seminar was blatant, and pro-Shi'a intellectuals and community leaders (such as Said Agil Siradj and Wahid ${ }^{65}$ ), as well as lay readers, ${ }^{66}$ responded vocally through the press. Nonetheless, the seminar's organizers were focused on their ultimate goal, taking advantage of the attention they were receiving, and of the momentum they had gained, having garnered statements of support from a number of national religious organization and MUI chairman Hasan Basri.

Although it might have been pure coincidence, albeit a suspicious one, an early consequence was that, at the earliest MUI meeting after the September 1997 seminar, the MUI approved a fatwa declaring nikah mut'ah to be haram. The topic of nikah mut'a had been reopened in May 1996 with Ali Hasan's trial and his conviction for desecration of religion (penodaan agama) and for having sex with a minor. Although during the trial it was recognized that nikah mut'a was, indeed, allowed in Shi'a Islam, ${ }^{67}$ in October of the same year the Ministry of Religious Affairs had issued a letter to the MUI requesting the release of a fatwa on temporary marriage.$^{68}$ It ought to be noted that this request had been ignored for a year. In fact, at the March 1997 National Working Session (RaKerNas) of MUI, Hasan Basri had rejected the proposal brought forward by several local and national branches of religious organizations, despite the case showing substantial evidence of the "social disruption" caused by the practice, and having the support of the East Java MUI chairman, K. H. Misbach. But in October 1997, the MUI issued the fatwa, claiming concerns "amongst parents, scholars, educators, civil society leaders, and Indonesia's Muslims in general, that [this practice] is considered a propaganda tool of Shi'a understanding in Indonesia," an understanding, it is then explained, "that Sunnis (ahlus Sunnah wal Jama'a'h) do not recognize and in fact fully reject." ${ }^{\prime 69}$

Just two days after the release of the nikah mut'ah fatwa, the LPPI proceeded to formalize its request to the minister of religious affairs and the Attorney General's Office to have Shi'ism declared by the state as heretical. In November, the AGO representative explained that, although the MUI had supported the request, the AGO could not proceed too quickly, as

before such a decision on the ban can be taken, usually the AGO would have to first pursue thorough research to verify the grounds of the complaints. This research, also, cannot be conducted by the AGO itself, but will involve several other parties like Bakin [intelligence agency], the police, the Ministry of Home Affairs, that of Religious Affairs, and Foreign Affairs. ${ }^{70}$

\footnotetext{
${ }^{65}$ See: "Ramai Menolak Syiah," Tiras, October 6, 1997, pp. 73-74; and "Siapa mau Syiah Sesat?" PanjiMas, April 21, 1997, p. 89.

${ }^{66}$ See: "Mengapa Syiah ditolak?" Tiras, October 20, 1997, p. 12; "Sesatkah Syiah?" Tiras, November 22, 1997, pp. 7-8; "Seminar tentang Syi'ah tidak ilmiah," PanjiMas, October 20, 1997, p. 7; "Buktikan bahwa Syiah tidak sesat," PanjiMas, November 17, 1997, in Mengapa kita menolak, p. 242; and "Seminar Istiqlal: Orang awam menjadi bingung," Ummat, November 10, 1997, pp. 11-12.

67 "Kawin mut'ah model Ali," Gatra, May 25, 1996, p. 89.

68 "Surat Sekretaris Jenderal Departemen Agama RI nomor BVI/ 4PW.01/4823/1996," October 11, 1996, mentioned in Dewan Pimpinan Majelis Ulama Indonesia, Surat Keputusan Fatwa tentang Nikah mut'ah, no. Kep-B-679/MUI/ XI/ 1997, October 15, 1997.

${ }^{69}$ Dewan Pimpinan, Surat Keputusan, October 15, 1997.

70 "Apakah karena Suni Mayoritas?" Tiras, November 10, 1997, in Mengapa kita menolak, p. 236.
} 
What is more, the decision would ultimately rest with Bakor PAKEM (Badan Koordinasi Pengawasan Aliran Kepercayaan Masyarakat, Coordinating Body for the Surveillance of Spiritual Movements in Society). ${ }^{71}$ This administrative detail is of utmost importance, since PAKEM had the task of monitoring "belief" (kepercayaan) organizations that the government did not consider to be religious groups (agama). ${ }^{72}$

The divergent attitude of representatives of the Ministry of Religious Affairs and MUI had already surfaced in the aftermath to the Istiqlal Mosque seminar, and these reactions are yet another window to the connection between anti-Shi'a discourses and national politics as the New Order regime struggled to survive, and other power stakeholders maneuvered peripheral issues for their own goals. Again, September 1997 is a turning point.

Tarmizi Taher, a former admiral and then minister of religious affairs, had the previous year expressed his disbelief that Shi'a Islam was "a problem" in Indonesia. He staunchly refused any suggestion that Shi'a Islam was present in the country, or that the ministry was even talking about the potential dangers of this aliran: "we are very solid in our belief in the ahlussunna wal jamaah. ${ }^{73} \mathrm{~A}$ few months later, commenting on the outcome of the Istiqlal seminar, Taher remained convinced that "we can't yet say [Shi'a] has spread. The Indonesian ummah is truly Ahlus Sunnah," and responding to the LPPI's request, he further added that "it [Shi'a Islam] is not easy to ban." ${ }^{74}$ This concern was echoed by another representative of the ministry, who glossed, "Yes, we really need to be careful with that [request to ban Shi'a Islam in Indonesia], because in any case that is the official religion in Iran." ${ }^{75}$

K. H. Hasan Basri initially took a similarly cautious approach, arguing that "if Shi'a Islam is made a deviation, [I would] fear disturbances to Indonesia-Iran relations." ${ }^{76}$ Within a mere six months he changed his mind. At the Istiqlal Mosque seminar, Basri had turned into a staunch supporter: "Of course we support the ban on Shi'a in Indonesia. Because us, here, are Ahlussunna, or Sunni. So if it's true that Shi'as' activities cause anxiety, yes, it has to be banned. ${ }^{\prime 77}$ Hasan Basri's and Tarmizi Taher's radically different reactions to the LPPI's request can both be explained by looking at the position of the Ministry of Religious Affairs and the MUI at this crucial moment of September 1997.

Whereas minister Taher's position was not threatened by changing power balances in the New Order regime and he could thus remain firm in his stand that "more research was needed" before any decision could be taken, Basri's behavior was exemplary of the changes induced by the ways in which the rules of the game were being transformed in late 1997. As reformist Islamic orthodoxy was gaining currency

\footnotetext{
${ }^{71}$ Ibid.

${ }^{72}$ For a discussion of agama and the formalization of religion in Indonesia, see Michel Picard, "Introduction: agama, adat and Pancasila," in The Politics of Religion in Indonesia: Syncretism, Orthodoxy, and Religious Contention in Java and Bali, ed. Michel Picard and Rémy Madinier (London: Routledge, 2011), pp. 1-20.

73 “Kita ini Ahlussunah wal Jama'ah," Tiras, February 15, 1996, p. 23.

74 "Lebih baik terbuka," PanjiMas, October 6, 1997, p. 87.

75 Ibid.

76 "Siapa mau Syiah Sesat?" PanjiMas, April 21, 1997, p. 89.

77 “Apakah karena Suni Mayoritas?” Tiras, November 10, 1997, in Mengapa kita menolak, p. 236.
} 
as political capital in opposition to the regime, the MUI could take a leap to emancipate itself from the now faltering government, moving away from its "regimist" position.

In the early months of 1998 , as the regime struggled to respond to the crisis, all political forces were working towards influencing the results of the upcoming session of the People's Consultative Assembly that was due to nominate the president and vice-president in March. In January and February, anti-Chinese sentiment was mounting, and "top government officials ... actively encouraged Islamic groups to amplify and act upon these anti-Chinese sentiments." ${ }^{78}$ According to Sidel, the nomination of Habibie as vice-president, and the concomitant sidelining of all potential cabinet members suggested by ICMI in favor instead of close allies to Suharto's family, "left Habibie-and the broader Islamic forces he represented-in a highly awkward and ambiguous position within the regime." ${ }^{79}$

It was in this context that Suharto offered the position of minister of religious affairs to Quraish Shihab, a member of both MUI and ICMI, but someone who also stood at the margins of this modernist organization. As laid out by $A U L A$, the East Java Nahdlatul Ulama bulletin, Shihab's nomination represented a break from the pattern of previous ministers. He was a graduate of al-Azhar University, a Hadhrami of sayyid descent, and a religious figure well known by the general populace across the archipelago, and also a scholar who "had been under siege as a Shi'a follower," probably due to his Shi'a-infused tafseer (commentary) publications. Indeed, the latter issue emerged immediately as controversial, with groups such as al-Bayyinaat, FOKUS (Forum Komunikasi Ulama Sunna, Communication Forum for Sunni Scholars, East Java), and LPPI voicing their concerns over the new minister being a Shi'a. Quraish Shihab's denial of these "accusations" was supported by both the NU leadership and Hasan Basri, thus allowing Shihab to retain his position until the Suharto regime eventually collapsed in May. ${ }^{80}$

The question remains, however, whether Suharto's choice of Shihab as minister was yet another move in his game of pitting the various power stakeholders one against the other. Disregarding ICMI's cabinet wish-list, Suharto pretended to give an "important" cabinet post-or supposedly so for a religious lobby-to a recognized religious public figure, but yet one who was absolutely unable to bridge the tensions internecine to the community because of years' long debates over his allegiance. With this choice, Suharto was undermining the religious party's ability to shape a strong opposition.

During the New Order, anti-Shi'a discourses had been initially driven by the government's political considerations over the transnational influence of the Iranian revolution's antiestablishment religious character, and in that way foreign dynamics had intersected with domestic questions of socio-political stability. In this phase, the marginalization of Shi'a Muslims and Shi'a sympathizers had come top-down through criminal cases, and bottom-up through stigmatization and condemnation of deviant behavior, substituting the terms of the opposition from socio-political to sociotheological. At the onset of Reformasi, Shi'ism was thus under scrutiny and doctrinal

\footnotetext{
${ }^{78}$ Sidel, Riots, Pogroms, Jihad, p. 113.

${ }^{79}$ Ibid., p. 116.

${ }^{80}$ "Dicintai Santri Dituduh Syiah," AULA, April 1998, pp. 65-68.
} 
attack, but the destabilizing transformations of 1997-98 and the shifts of 1998-2001, most relevantly marked by the rapid rise and fall of Islamic reformism, had prepared the ground for a second phase in anti-Shi'a trends, now characterized by physical violence towards an officially recognized group of believers.

\section{Standing Behind the Line: Recognition and Victimization}

\section{Bandung, West Java}

On July 1, 2000, at Bandung's "Independence Building," Jalaluddin Rahmat announced the establishment of IJABI as a recognized "Islamic civil society organization truly independent and free from ties with political parties." ${ }^{81}$ IJABI was intended to be an organization gathering those members of society that "until now have been marginalized," and one committed to the empowerment of the weak. "IJABI is not an ormas just accommodating the Shi'a, but this is an organization that is open to all madhhab and Islamic groups in Indonesia." ${ }^{82}$ Its first congress, opened two days later, was attended by more than two thousand people from twenty provinces across the archipelago. ${ }^{83}$

\section{Batang, Central Java}

On a Friday afternoon, around two o'clock, a spontaneous mob attacked a pesantren. This was not just any given Friday, as April 14, 2000, corresponded to the ninth day of Muharram. The attack was described as spontaneous; reportedly, ribuan [thousands] of attackers had converged on a recently erected building belonging to al-Hadi, a wellknown Shi'a pesantren headquartered in Pekalongan, about four miles away. Following no specific order, in under an hour, the mob had injured over thirty students, caused damages totaling about fifteen million rupiah (in today's dollars, US\$18,000), and forced the pesantren to relocate its activities. By that evening, all demonstrators had dispersed, none had been arrested, and the pesantren remained under police guard. ${ }^{84}$

The opening up to religion of both civil society and the political sphere in the postSuharto era has been both a blessing and a curse for the position of Shi'a Islam in Indonesia. A champion of religious pluralism, Abdurrahman Wahid, as fourth president of the Republic (1999-2001), approved the recognition of IJABI as a legal mass organization (ormas). Yet, this step did not erase past history, and the road towards the legitimation of Shi'a Islam as a branch (aliran) that falls within the pale of Islam was still uphill.

IJABI had taken shape under the leadership of Jalaluddin Rakhmat. Although his public figure as "a Sunni with a deep knowledge about Shi'a" was gradually shifting towards a more open labeling as Shi'a, throughout its existence IJABI has been able to

\footnotetext{
${ }^{81}$ For a full exploration of Jalaluddin Rakhmat, see Zulkiflili, The Struggle, pp. 88-107.

82 "Kang Jalal: Tujuan IJABI Berdayakan Kaum Lemah," Pikiran Rakyat, July 2, 2000.

83 "Ijabi dideklarasikan di Bandung," Kompas, July 4, 2000, p. 20.

${ }^{84}$ See: "Pondok pesantren dirusak massa," Jawa Pos, A pril 16, 2000, p. 14; and "Rusuh, pesantren al-Hadi masih dijaga ketat," Suara Merdeka, April 16, 2000, p. iii.
} 
embrace a wide community, leaving the door open to "the lovers of the ahl al-bayt regardless of their madhhab ${ }^{\prime \prime 5}$ while retaining the prerogative of public advocate and defender of Shi'a rights as a religious minority (most importantly, by representing in court Shi'a victims of religious discrimination).

\section{From Words to Action}

At the same time as President Wahid was showing his commitment to fostering a plural society, a spontaneous mob attacked one of the key Shi'a educational institutions in Java. The pelting of al-Hadi in Pekalongan with stones would not be an isolated case, nor would it be the most heinous display of anti-Shi'a violence. What is more, the Shi'a are not the only Muslim minority whose legitimacy is being challenged; the violence against the Ahmadiyyah sect was and remains most notable. Surrounded by controversy, stigmatized by other Muslims across the world, marked by a long record of oppression and marginalization, and followed by a small and well-delimited membership (as opposed to the "blurry boundaries" of "cultural Shi'ism" in the archipelago), this sect has been the victim of a systematic strategy of eradication throughout the twentieth and twenty-first centuries, more so than the Shi'a. In the already tense climate of the early 2000s, anti-Ahmadiyyah attitudes have also been affecting the treatment of Shi'a Muslims. Shortly after the June 2008 decree against the Ahmadiyah, a banner appeared briefly in the Ampel neighborhood of Surabaya announcing that the Shi'a would be the next target. ${ }^{86}$

In September, and again in December, 2006, the Bondowoso (East Java) IJABI representative and his congregation of about 150 followers were attacked with stones; ${ }^{87}$ in November 2007 the houses of YAPI pesantren caretakers were ransacked by an "antiShi'a mob"; ${ }^{88}$ on January 9, 2008, or the first day of Muharram 1429, police prevented an attack on Shi'a Muslims in Mataram (Lombok). All participants were escorted home by police, and their prayer group al Qurba was directed to cease all activities, but no one was arrested..$^{89}$ In mid-February 2011, a YAPI branch in Pasuruan, also in East Java, was attacked by a mob numbering about a hundred people, leaving two injured guards and one injured student. ${ }^{90}$ In December of the same year, another mob pursued a first attack against the Shi'a community in Sampang, Madura. ${ }^{91}$ Similar instances of

\footnotetext{
${ }^{85}$ Mission statement of the all-Indonesian Assembly of Ahlul Bait Associations (Ikatan Jama'ah Ahlul Bayt, IJABI), http: / / www.majulah-ijabi.org/ visi-dan-misi.html, accessed August 11, 2014. In his proclamation speech, Jalaluddin also stated: "In IJABI right now, in fact, many people come from many different madhhab and groups. They are all united in their love for God, the Prophet Muhammad, and his Ahlul bait." See: "Kang Jalal: Tujuan IJABI Berdayakan Kaum Lemahi," Pikiran Rakyat, July 2, 2000.

${ }^{86}$ Ahmadiyyah's persecution dates to the early days of its appearance in colonial Indonesia. See: Melissa Crouch, "Tudicial Review and Religious Freedom: The Case of Indonesian Ahmadis," Sydney Law Review 34 (2012): 545-72; and Ricklefs, Islamisation and Its Opponents, p. 441.

${ }^{87}$ See: "Massa bubarkan pengajian IJABI," Jazva Pos, December 25, 2006, p. 9; and "IJABI stop pengajian," Jawa Pos, December 26, 2006, p. 12.

88 "Serbuan Sesuai Pengajian," Majallah Tempo, February 27, 2011, pp. 38-39.

89 "Police in Indonesia's Lombok Prevent Attack On Shia Group," BBC Monitoring Asia Pacific, January 16, 2008, from Republika, January 14, 2008.

${ }^{90}$ See: "Serbuan Sesuai Pengajian," pp. 38-39; and "Ratusan orang serang santri Ponpes Yapi di

Pasuruan," Jawa Pos, February 16, 2011, p. 1.

91 "Pesantren Syiah dibakar," Majallah Tempo, January 8, 2012, p. 72.
} 
violence would continue throughout 2011-13, ${ }^{92}$ with a geographical focus on East Java, ${ }^{93}$ but there were also sporadic events in the other islands. On October 31, 2012, a group of Shi'a in Ternate come under attack, ${ }^{94}$ and a month later the IJABI Ashura event in Makassar became the target of one hundred members of the radical group Front Pembela Islam. ${ }^{95}$

After the first attack in April 2000, additional violence took place between 2006 and 2013 in a rapidly changing political context, where relations among religious groups and state organs, as well as between different religious groups, were often being redefined and transformed. It was, in fact, amidst the frustration of Islamist aspirations and excitement towards democratic, liberal, and pluralistic politics that in 2000 the Shi'a community found itself trapped between encouragement and victimization.

The failure of Habibie and the Islamic parties to instate a religiously inclined majority in parliament in 1999 (and again in 2004, despite high expectations for the Partai Keadilan Sejahtera, or Prosperous Justice Party, PKS) was a major blow to those hoping for the further solidification of Islam in politics. And Abdurrahman Wahid, chairman of Nahdlatul Ulama, was far from the ideal president for politicized Muslims, as is testified by his promotion of liberal Muslims, secularists, and Christians to important cabinet roles, and his championing of IJABI. Focusing further on the disappointment of politicized "orthodox" Muslims, these groups "concerned" with the status of Islam in the country eventually exited the arena of formal politics and stepped into society. Sidel argues that the anti-Christian jihad waged in Poso and Maluku in 2000-01 and the bombings that occurred between 2000 and 2004 were "a symptom of the weakness of those who have tried to mobilize in [Islam's] name." ${ }^{96} \mathrm{He}$ focuses on violence against non-Muslims, as it was the "upward push" for the recognition of Islam that had induced the confrontation between Muslims and "the stubborn residues of Christian and Chinese power in the hierarchies of state and market." ${ }^{97}$ In the remainder of this article, I widen the scope of Sidel's argument beyond a Muslim-nonMuslim dicothomy, using his analysis to understand the rise in intra-Muslim tensions.

The very process of Islam's settlement in this "upper" locus and its rapid fall had emboldened mainstream groups (such as ICMI, MUI, LPPI, and FPI) to uphold as the rule a modernist embodiment of Sunni Islam. When militant groups were not suppressed by the military or the government, but only forced to close their jihad front

\footnotetext{
92 This article, written between May and August 2013, reflects the state of things up to that point. In the months that have followed there have been increased tensions between Sunni and Shi' $i$ groups, both at the local and national levels.

${ }^{93}$ Due to space constraints, the local religious context of East Java has not been included here, but it is important to bear in mind NU's predominance in this region, the legacy of the 1960s re-Islamization of the area, and, as pointed out by Ricklefs, this region's religious actors' commitment to a continued condemnation of deviance in the 2000 s. Ricklefs, Islamisation and lts Opponents, p. 336.

94 "Jamaah Syiah Ternate ogah turuti kemauan warga," The Wahid Institute, November 7, 2012, available at wahidinstitute.org/v1 / Program/Detail / ?id=460/ hl=id/Jamaah_Syiah_Ternate_Ogah_Turuti_Kemauan_ Warga, accessed August 11, 2014.

95 "FPI Sulsel Demo Peringatan Asyura Kelompok Syiah di Makassar," detikNews, November 24, 2012, available at http: / / news.detik.com/ read/2012/11/24/072550/2100037/ 10/ fpi-sulsel-demo-peringatanasyura-kelompok-syiah-di-makassar, accessed June 22, 2014.

${ }^{96}$ Sidel, Riots, Pogroms, Iihad, p. 217.

${ }^{97}$ Ibid., p. 136.
} 
in Poso and Maluku (the "terrorist" bombings of Bali and Jakarta being a different matter that is of little relevance here), these militants found their niche in Indonesian society as enforcers of the religious dictum al amru bil-ma'ruf wan-nahyu'an-il-mun'kar (to command the good and forbid the evil), thus focusing on ensuring "proper Islamic behavior"-Sunni Islam. Frustration at political marginalization was not channeled against "non-Muslims," but instead escalated to responding to "perceived insults" from "other Muslims."

As statements attempting to preserve and regulate Islamic orthodoxy multiplied in the 2000s, Indonesia experienced a rise in cases of intra-Muslim intolerance. However, it ought to be noted that these discourses were not being formulated at the grassroots, but rather by supra-societal actors, meaning semi-official bodies and representatives. Although these are a nebulous and vague category of actors, which at some level are indeed in touch with society, it is nonetheless useful to distinguish between government-affiliate or government-like actors and individual citizens who might join groups or act individually. In this context, mob attacks against "nonorthodox" Muslims have also increased, with anti-Shi'a statements and actions becoming more common, widespread, and terrifying in their outcome.

\section{Escalation}

The case of the Shi'as of Nangkernang is an exemplary case of how local tensions became mobilized along "sectarian" lines through politicized discourses of religious identity. A sequence of political reactions led to the transformation of a family quarrel into a trigger for conflict, one which escalated along religious sectarian lines. Similarly to the "anti-Communist" violence that ensued from the alleged coup of September 30, 1965, and the Christian-Muslim "communal conflict" that plagued Maluku islands in 1999-2001, the Sampang anti-Shi'a violence became a way to channel grievances into an easily recognizable pattern of mobilization.

On December 29, 2011, about five hundred armed men approached the complex housing the Shi'a pesantren Misbahul Huda. They had been informed by a local religious community leader, Roisul Hukama, that a praying session was taking place there. Within an hour, the mob had destroyed and set fire to the boarding school, with two policemen passively watching over the scene. From there, they moved to another house, about one kilometer away, and burnt that down, too. At about noon, they reached ustadh Tajul Muluk's house, which was also set on fire. According to the mainstream narrative, ${ }^{98}$ this was the first attack against the Shi'a community of Nangkernang, and it is, to my knowledge, the first time that the local and international news referred to an anti-Shi'a attack in Indonesia as sectarian.

Tensions, however, were not new in the village, as its Shi'a community had experienced intimidations and attempts at eradication since 2004, shortly after Misbahul Huda was established by Tajul Muluk, with the help of teachers from YAPI, in Bangil. By 2006, his influence had spread to a community of several hundred believers, including his own younger brother, Roisul Hukama. Within one more year

98 "Shia Followers Hide in Hunger," The Jakarta Post, A ugust 28, 2012, available at http: / / www.thejakarta post.com/news/2012/08/28/ shia-followers-hide-hunger.html, accessed July 22, 2014. 
the two brothers had attracted not only the attention of IJABI leaders, who made them representatives to Madura, but also that of a group of local radical Sunnis, who on the day of Maulud Nabi led a protest against the Shi'a group's celebration, which was attended by hundreds of villagers. This was an event of little consequence, and, in fact, nothing further happened until 2009, when Roisul Hukama decided to "return to the Sunna."

According to a Tempo report, as well as an interview that I conducted with Jalaluddin Rakhmat in November 2011, ${ }^{99}$ Roisul's sudden change of heart was induced not by theological considerations, but rather by a girl. As Tajul officiated the marriage between a Misbahul Huda pupil and a girl from the neighboring pesantren where Roisul was teaching, Roisul felt betrayed for not having been involved in the events that led to the marriage. Apparently, he wanted to take the girl as his own wife. As trivial as this might sound, Roisul then "returned to the Sunna" and began, or further ignited, an anti-Shi'a campaign in the area.

When Tajul Muluk refused to abandon Shi'a Islam and "revert to the ahl al-sunna" (People of the Sunna), he was forced to go into exile in Surabaya, on the neighboring island of Java. Eventually, in April 2011, the Badan Silaturahmi Ulama Madura requested that the entire community move off the island. Upon the Shi'is' refusal to follow such a proposition, meetings ensued in May and August with both MUI Madura and the regional FORPIMDA (Forum Pimpinan Daerah, Forum for Regional Leadership) discussing the Shi'a position on the island. Tensions gradually escalated, attracting international attention. In September, for example, Human Rights Watch researchers investigating the discrimination of the Shi'a community were arrested by police for "interviewing Syiah followers in the village." ${ }^{100}$ The destruction described above took place in December 2011, just a couple of weeks after Ashura commemorations had taken place. Eight months later, on August 26, a second mob, also numbering about five hundred individuals, stormed the Shi'a village for a second time, brandishing machetes and throwing Molotov cocktails. Although in 2009 MUI Sampang had refrained from making any statements, and the tension then had not escalated into violence, in May 2011 the MUI Madura voiced specific concerns about the spreading of Shi'a Islam in the region, legitimating the mob's action against Misbahul Huda in December of that year. Moreover, on January 1, 2012, just a few days after that attack, MUI Sampang issued an edict describing Shi'a as deviant and the supervising branch, MUI East Java, issued a full-fledged fatwa on January 21 with a text that relied also on Yusuf al-Qaradawi's opinion. Official condemnation was not limited to declarations from religious authorities. Lending support to the now-inverted relationship between state and MUI, on March 16 the East Java police charged Tajul Muluk with blasphemy, an accusation later substantiated by the Sampang district court, further inducing the East Java governor to issue a regulation on religious deviancy that included Shi' ism. ${ }^{101}$

\footnotetext{
${ }^{99}$ Interview with Jalaluddin Rakhmat, Jakarta, November 24, 2011.

100 “2 Human Rights Watch Researchers Arrested in Sampang," The Jakarta Post, September 20, 2011, available at http: / / www. thejakartapost.com / news/2011/09/20/2-human-rights-watch-researchersarrested-sampang.html, accessed July 22, 2014.

${ }^{101}$ Possibly because of its tragic ending, and the great deal of attention that it has received by journalists and NGO activists, the local circumstances that led to the violence of December 2011 and again August 2012 are well documented. The sequence of events has been reconstructed on the basis of the many articles
} 


\section{Determining Causality in a Broader Context of Discrimination}

Following up from this account and what has been said about the longer string of attacks, any explanation of the rise in anti-Shi'a violence in post-New Order Indonesia needs to be placed at the intersection of locally grounded social and political dynamics and religious bodies' deliberations. In fact, as random as the sequence of attacks appears to be, ${ }^{102}$ upon reading these cases against the broader political environment and specific statements and decisions by regional or national leaders of mainstream Islamic organizations on questions of orthodoxy and deviancy, one can see a pattern emerge, as noted below.

The $\mathbf{2 0 0 0}$ attack on al-Hadi had followed the prohibition, issued two weeks earlier by the Batang Attorney's office, for the pesantren's erecting a new building. ${ }^{103}$

The 2006 attacks against the IJABI congregation in Bondowoso followed the 2005 MUI's fatwa defining the Ahmadiyyah as "deviant." 104

The 2007 attack on a Shi'a house in Bangil took place three weeks after the MUI's deliberation listing the criteria to identify "deviant groups." ${ }^{105}$

The disturbance of Mataram's Shi'a community on the first day of Muharram in 2008 was the culmination of intimidations started after the city's mayor issued a declaration of deviancy in June 2003. ${ }^{106}$

The 2011 attack on YAPI took place less than a week after the Ahmadiyyah leader's residence was attacked in Cikeusik, West Java, on which occasion at least three community members were killed. ${ }^{107}$

Two attacks in Jember in January 2013 ensued after the advertisement of the East Java MUI and governor's declarations of deviancy in August 2012 and a District Council's meeting held to discuss Shi'a in the area. ${ }^{108}$

that were published in the days and weeks following the attack; most relevant are two Majallah Tempo issues, dated January 8, 2012, and January 15, 2012, respectively. See also "Inilah Kronologis Kekerasan Warga Syiah di Sampang," Suara Pembaruan, August 27, 2012, available at http:/ / www.suarapembaruan. com/ home/ inilah-kronologis-kekerasan-warga-syiah-di-sampang/23865, accessed July 22, 2014; and "Bagaimana Kronologi Syiah Masuk Sampang?" Tempo.co, September 2, 2012, available at http: / / www.tempo.co/ read/ news/2012/09/02/173426989/Bagaimana-Kronologi-Syiah-MasukSampang, accessed July 22, 2014. The MUI fatwas are collected in Ainul Yaqin, ed., Fatwa dan keputusan MUI tentang ajaran Syi'ah (Surabaya: MUI Provinsi Java Timur, 2012).

${ }^{102} \mathrm{Or}$ at least those attacks that have been documented by the press and which I was able to find. I have to assume that this data is complete enough to reflect actual trends, even though some instances may not have been recorded, or may have escaped my scrutiny of the sources.

103 "Pondok pesantren dirusak massa," Jawa Pos, A pril 16, 2000, p. 14.

${ }^{104}$ Wawan H. Purwanto, Cikeusik Tragedy: A Lesson from Ahmadiyah Case (Jakarta: CMB Press, 2012).

${ }^{105}$ Keputusan RaKerNas MUI tentang pedoman identifikasi aliran sesat, November 6, 2007, in Fatwa dan keputusan, pp. 91-100.

${ }^{106}$ See: "Walikota Mataram larang penyebaran Islam Syiah," Koran Tempo, June 4, 2003, p. B7; and "Syiah Ahlul Bait kecewa atas larangan walikota," Koran Tempo, June 5, 2003 , p. B7.

${ }^{107}$ Purwanto, Cikeusik Tragedy.

${ }^{108}$ See: Arif Purba, "Spanduk Anti-Syiah Bertebaran di Jember," Jaring News, August 29, 2012, available at jaringnews.com/ politik-peristiwa/ umum/21646/spanduk-anti-syiah-bertebaran-di-jember, accessed July 22, 2014; Arif Purba, "Konflik Syiah Dengan Ahlussunnah Wal Jamaah Jember Mencair," Jaring News, August 30, 2012, jaringnews.com/ politik-peristiwa/ umum/21775/ konflik-syiah-dengan-ahlussunnah- 
Since the year 2000, statements and deliberations by the government or religious organizations have anticipated episodes of violence, as these institutions worked on the assumption that Shi'as will cause trouble, disrupting social harmony and weakening Sunni orthodoxy. Although these assumptions existed in the New Order era as well, at that time anti-Shi'a deliberations were either aimed at protecting the Sunnis by encouraging them to keep their practices close to the teachings of the ahl alsunna wa-l-jama'ah, literally "the people of the tradition and of the community" and used to refer to Sunni practices (as expressed in the 1984 tawsiya, for example), or criticized specific Shi'a practices that had been (allegedly) involved in cases that had upset social stability.

In sum, through reformasi, the role of anti-Shi'a resolutions have changed from "response" to "cause" of conflict. Whether claiming "disruption of social harmony" or, as has happened often in the post-Suharto era, "doctrinal deviation," actors such as the AGO, MUI, and NU are responsible for instigating reprisals against those who "threatened" peace by falling out of (arbitrary) definitions of orthodoxy. This is not an isolated case, and similar examples can be drawn from the anti-Ahmadiyyah violence. ${ }^{109}$ Moreover, the changed causality relates well to the observed reshaped status of the Majelis Ulama Indonesia vis-à-vis the state, as the former has been transformed from recipient to giver of influence on religious matters. ${ }^{110}$

Throughout the New Order, the main drive behind anti-Shi'a discourses was consistently the state with its concerns for maintaining social stability (see the 1984 tawsiyah and the reactions to the Borobudur bombings and the nikah mut'ah cases). Yet the state (and MUI, which was part of the state's machinery), opposed responding positively to religious organizations' requests to ban Shi'a Islam in the country until 1997. It was only towards the end of that year that MUI, through its chairman Hasan Basri, changed position. This, we saw, was part of Basri's attempt to distance himself (and MUI) from the faltering regime. After 1998, and most notably since 2005, religious concerns-as voiced by the MUI-have become a major factor in influencing related policies.

\section{Explaining "Religious Violence"}

These connections and patterns still fall short of explaining why the Shi'as have been attacked and why people gathered in a mob-as an unorganized group aimed at causing havoc-to take action against a Muslim minority. And why are people becoming increasingly susceptible to participating in these actions?

wal-jamaah-jember-mencair, accessed July 22, 2014; “Isu SARA, Toko-toko di Jember Dirusak Massa (Video), VivaNews, January 26, 2013, us.nasional.news.viva.co.id/ news/ read/385411-video--isu-sara-toko-toko-di-jember-dirusak-massa, accessed July 22, 2014; and "Di Jember, Penyerangan Warga Syiah Berhasil Digagalkan" available at http:/ / www.madina-online.net/index.php/wacana/pluralisme/423di-jember-penyerangan-warga-syiah-berhasil-digagalkan, accessed August 11, 2014.

${ }^{109}$ Despite the mentioned differences among the Shi'a and Ahmadi groups, which do limit the scope of a detailed comparison of the two phenomena, the interaction between physical attacks-mostly pursued by the FPI-and "process[es] of deliberation involving MUI, Bakor Pakem, and the Muspida, in addition to other elements of the local bureaucracy" in the post-1998 era, as described by Hicks, bears much similarity. See: Jacqueline Hicks, "Heresy and Authority: Understanding the Turn against Ahmadiyah in Indonesia," Southeast Asia Research 22,3 (September 2014): 321-39.

${ }^{110}$ Olle, "The Majelis Ulama Indonesia," p. 106. 
In the preceding pages I connected the shaping of anti-Shia discourses in the 1980s90 s and their transformation into violent attacks in the early 2000 s to developments in international politics (the Iranian revolution of 1979), international relations (IranIndonesia trade agreements), national politics (regime change), the national legal context (civil and religious provisions), national religious contexts (state-imposed orthodoxy), the broader environment of religious conflicts in the archipelago, and the context of local disputes.

Anti-Shi'a opposition in Indonesia rested on decades of "othering," but physical violence started with an isolated event in the year 2000, followed by an eruption of violence in 2006-13. Besides the heightening of anti-Ahmadiyyah voices, the sharpening of the Sunni-Shi'a dichotomy can be seen to be a reaction to the ousting of Islam from power with the ascension of Megawati Soekarnoputri as president of the Republic in 2001. Such phenomena, which accompanied the rising role of the MUI (the differences between its central and local branches notwithstanding), have also been identified as crucial for the communalization of the Maluku conflict between late 1999 and 2001. In their respective works, both Sidel and van Klinken explain the mobilization and polarization of the Poso and Ambon conflicts along religious lines at a time when political Islam was losing ground in Jakarta, therefore affecting consequences on local networks of patronage. ${ }^{111}$

As the New Order regime collapsed, the "unarmed urban crowds" that disappeared as rapidly as they had emerged to defend the integrity of Islam in Java's provincial towns in 1995-97 were replaced by "crudely armed" rural youths in 1998 and continuing into the 2000s. Still defined as a mob, they were able to coordinate their attacks (which remained localized) while remaining decentralized. Violence was not limited to unpredictable acts by the massa, the mob. By late 1998, Jakarta witnessed the emergence of religious vigilante groups sanctioned by the state. About a year later, as the conflict in Poso and Ambon escalated and perpetrators and victims became one and the same, religiously affiliated militias, mostly made up of locals but also including outsiders that had come to join the fight "in the name of religion," were headquartered in places of worship. ${ }^{112}$

A combination of the mobilization that occurred along ethnic and religious lines and Indonesian journalists' inexperience in reporting about conflicts probably caused newspapers" coverage to focus on the rioting and attacks "in a confined spatiality and temporality," ignoring the historical and socio-political perspectives. ${ }^{113}$ The conflict rapidly took the tone of a Muslims versus Christians conflict, and as the violence in Maluku has been broadly, and summarily, described as "religious," "communal," and "sectarian," it took years for scholarly works that suggested a more nuanced narrative to make an impact. Van Klinken has been one of the strongest voices in criticizing the purely instrumentalist or primordialist approach that dominated the debate in the early 2000s. Pursuing instead a grounded analysis of the conflict, he suggested the

\footnotetext{
${ }^{111}$ See: Sidel, Riots, Pogroms, Jihad, pp. 180-81; and Van Klinken, Communal Violence, pp. 102-3.

112 Sidel, Riots, Pogroms, Jihad, pp. 192-94.

${ }^{113}$ Stanley, "The Media as a Control and as a Spur for Acts of Violence," in Violent Conflicts in Indonesia: Analysis, Representation, Resolution, ed. Charles Coppel (London: Routledge, 2006), p. 201. See also Ati Nurbaiti, "Media Coverage of the Maluku Conflict in Indonesia," in Media and Conflict Reporting in Asia, ed. Shyam Tekwani (Singapore: Asian Media Information and Communication Centre, 2008), pp. 36-49.
} 
violence was "the result of interaction between long-term 'primordialist' social pathologies and a short-term instrumentalisation of those pathologies in the context of intra-elite competition at the local level." ${ }^{114}$ His assessment thus advocated that the reasons for the violence did not lie in religious motives per se, but that the trigger and fight "quickly acquired a purely religious character," with alliances subsequently falling along religious lines. ${ }^{115}$

Although I have lent much endorsement to Sidel's political analysis as I expanded on his suggestion that the modalities of the emergence of "religious" violence in the archipelago in the late 1990 s to early 2000 s were shaped by the competing articulations of claims to representing Islam, I am also interested in offering a more rounded explanation inspired by van Klinken's multi-layered approach to the "communal" conflict in Poso and Maluku. Thus, I conclude with a reflection on the sociological context in which villagers turned into mobs, looking at this transformation through the lens of an anthropological contribution to the understanding of violence in 1997-98, James Siegel's "Witch, Suharto." ${ }^{116}$

In his captivating study of the anti-witchcraft campaigns, Siegel rejects the framework of communal politics in the faltering state, suggesting instead "a collapse of the structures that generate identities and the subsequent surge of untamed impulses." No one acted in the name of God, each episode took place independently from the others, and none of the actors embraced a coherent political or religious identification. Rather, these "clusters of unselfconscious young men" acted as a mob. ${ }^{117}$ The same massa that the press indicated as responsible for the anti-Shi'a attacks. Yet, the massa cannot be held responsible at all as this is an ungraspable entity, a "phantasmatic force," "violent and unaccountable," whose actions "nee[d] no further reason," 118 making it the perfect perpetrator of local violence. The relationship of the mob to its own village highlights the importance of local and exogenous factors. The massa takes shape within a village (hence the importance of local disputes in the reconstruction of events), but it is both "evidence of a breakdown of identities ... caused by forces that arose outside the village" and an "attempt to restore identity by the use of a word recognized from descriptions of national events." ${ }^{119}$ This analysis turns the perpetrators into passive subjects as national and local shifts interacted, thus creating a distiction between Siegel's massa and Sidel's militants, who appear instead as actors actively responding to those shifts.

Focusing our attention on the victims, by 1998 the witch had become the local embodiment of an as-of-yet unidentified threat to the nation. But with the gradual strengthening of discourses of Islamic orthodoxy in the Indonesian public sphere, during the 2000s Shi'a Muslims-as well as the Ahmadis-became the new representatives of the threat to social order.

\footnotetext{
${ }^{114}$ Gerry van Klinken, "The Maluku Wars: Bringing Society Back In," Indonesia 71 (April 2001): 1.

115 Ibid., p. 7.

${ }^{116}$ Siegel, "Suharto, Witches," pp. 27-78.

${ }^{117}$ Ibid., p. 52.

${ }^{118}$ Ibid., p. 72.

${ }^{119}$ Ibid., p. 55.
} 
